\title{
INVENTORY INFORMATION SYSTEM DESIGN AT PT. ARSEN KUSUMA INDONESIA JAKARTA
}

\author{
Dahlia Sarkawi $^{1}$, Dani Ramdani ${ }^{2}$, Anggi Oktaviani ${ }^{3}$, Deny Novianti ${ }^{4}$ \\ Administrasi Perkantoran, Sistem Informasi \\ Universitas Bina Sarana Informatika \\ www.bsi.ac.id \\ dahlia.dls@bsi.ac.id_denynov.dov@bsi.ac.id \\ Sistem Informasi, Teknik Informatika \\ STMIK Nusa Mandiri \\ www.nusamandiri.ac.id \\ 12170497@nusamandiri.ac.id,anggi.aov@nusamandiri.ac.id
}

\begin{abstract}
Abstrak
Sistem Informasi Inventory adalah sebuah Sistem Informasi yang menyediakan informasi dari beberapa proses yang meliputi pengadaan barang, pergudangan dan pelaporan. Oleh karena itu perlu dibuat suatu aplikasi Sistem Informasi Inventory untuk meningkatkan proses kinerja perusahaan yang semula manual menjadi terkomputerisasi yang akan menghasilkan laporan yang lebih terinci. Pembuatan aplikasi ini dilakukan dengan cara pengumpulan data, perencanaan sistem, analisa sistem, perancangan sistem dan database. Pembuatan program aplikasi dikembangkan dengan PHP dan model Waterfall serta di uji menggunakan black-box testing. Dan diharapkan pembuatan aplikasi ini dapat mempermudah perusahaan dalam mengolah persediaan barang, maka dalam penelitian ini dibuatkan Perancangan Sistem Informasi Inventory Pada PT. Arsen Kusuma Indonesia Jakarta.
\end{abstract}

Kata kunci: Sistem Informasi; Persediaan; Model Waterfall

\begin{abstract}
An inventory Information System is an Information System that provides information from several processes including procurement of goods, warehousing, and reporting. Therefore it is necessary to create an Inventory Information System application to improve the company's performance process which originally became computerized which will result in more detailed reports. The creation of this application is done using data collection, system planning, system analysis, system design, and database. Application program creation was developed with PHP and Waterfall model as well as tested using blackbox testing. And it is expected that the manufacture of this application can facilitate the company in processing the inventory of goods, then in this research was made Designing Inventory Information System At PT. Arsen Kusuma Indonesia Jakarta.
\end{abstract}

Keywords: Information Systems; Inventory; Waterfall Model

\section{PRELIMINARY}

Inventory is an activity concerning activities and transactions in and out of goods in a company. Because inventory is so important to the company, the existence of an inventory system is needed to facilitate the recording and processing of transactions in and out of goods at the company. (Irfana, 2017). Inventory is very important for the survival of the company (Salangka, 2013), (Barchelino et al., 2016). The company must be able to estimate the amount of inventory it has (Suharti \& Fong, 2018). Inventories owned by the company should not be too much and also not too little because it will affect the costs that will be incurred for the inventory (Salangka, 2013). Without an inventory, the entrepreneur will be faced with the risk that his company at one time will not be able to meet customer requirements (Banuwati et al., 2015), who require or request goods/services (Kushartini \& Almahdy, 2016).

Inventory is the stock of goods or storage of goods (Stevenson \& Chuong, 2014). To the number of items stored which will be used later. By designing the system towards a better direction, it is hoped that it can help and facilitate 
the ongoing system process so that it makes it easier to manage data including processing, compiling, storing, and manipulating data which ultimately produces accurate data that can be used for company needs. (Irfana, 2017). An inventory information system was created and developed using the Waterfall model (Frieyadie, 2015). This system is a unit consisting of components or elements that are linked together to facilitate the flow of information, material, or energy to achieve a goal (Palit et al., 2015). For that, the system is said to be a good system with characteristics (Hutahaean, 2015) namely: Components, System Boundaries, External Environment, System Connectors, System Inputs, System Outputs, System Processors, System Objectives.

The purpose of this research is to make it easier for companies to process inventory so in this study the Inventory Information System Design at PT. Arsen Kusuma Indonesia Jakarta.

\section{RESEARCH METHODS}

Obtain data by conducting research, directly and indirectly, to get it right using the following data collection model:

1. Interview, the author conducts direct interviews with the inventory officer or employee.

2. Observation, the researcher made direct observations on the existing inventory system at PT. Arsen Kusuma Indonesia.

3. Literature Study Namely by finding and studying relevant books to provide a better understanding of the topic of writing and enrich the writer's knowledge about computer networks.

\section{Types of research}

This study uses a qualitative research method approach, which means that data is all information both oral and written, even in the form of pictures or photos, which contribute to answering research problems as stated in the problem formulation or research focus. (Rahardjo, 2011).

\section{Research Target/Subject}

The target of this research is to assist and facilitate the ongoing process of the system to facilitate data management including processing, compiling, storing, and manipulating data which ultimately results in inaccurate data that can be used for corporate purposes.

\section{Research Methodology}

Research is often described as a process of the investigation carried out in a planned, orderly, and systematic manner that aims to find, interpret and revise facts.

\section{Research Stages}

This research was conducted by implementing it in several stages, namely as follows:

1. Literature Survey

In this initial stage, the researcher collected sources and information related to the research.

2. Identification of problems

Identifying problems to be discussed, relating to the Inventory Information System Design at PT. Arsen Kusuma Indonesia Jakarta is based on the sources and information that has been obtained.

3. Literature review

Researchers studied theoretical books about Inventory Information System Design which will be used as a theoretical study in research.

The information system development model used is the waterfall model. Is the model most widely used for the development stage. This waterfall model is also known as a traditional model or classic model (Pressman, 2003). Waterfall model (waterfall) is often called a linear sequential model (sequential linear) or classical life flow (Classic cycle) " (Susilo et al., 2018).

\section{RESEARCH RESULTS AND DISCUSSION}

The method used in developing this software uses the waterfall model method which is divided into several stages, namely:(Agus Prayitno, 2015).

\section{A. Software Requirements Analysis}

Requirements analysis is a requirement that is needed in designing a system designed by the author, this needs analysis is necessary for designing this proposed system and the needs of this system user.

\section{User Requirements}

The inventory application has one user who interacts with the system, namely the warehouse admin section. One user chooses the characteristics of the interaction with different systems and has different information needs, such as the warehouse admin needs scenario:

a. Provide information about the items needed.

b. Receive and check requests for goods that have been ordered by the Supplier. 
c. Input reports of incoming goods and goods out of the warehouse to the Supplier.

\section{System Requirements}

a. Users must log in first to be able to access the system by entering their username and password so that the privacy of each user is maintained.

b. After the Warehouse Admin logs in, the Warehouse Admin can use the incoming goods menu, stock items, demand for goods, incoming and outgoing goods that are in the system according to the level access owned by the Warehouse Admin.

c. The system can store and manage admin data, item data, and reports.

d. After the Warehouse Admin uses the system, it is required to log out so that it can log back in when using the system again.

\section{B. Design}

\section{System Modeling Design}

The following is a warehouse inventory system software design at PT. Arsen Kusuma Indonesia, which will be described below.

a. Use Case Diagram modeling

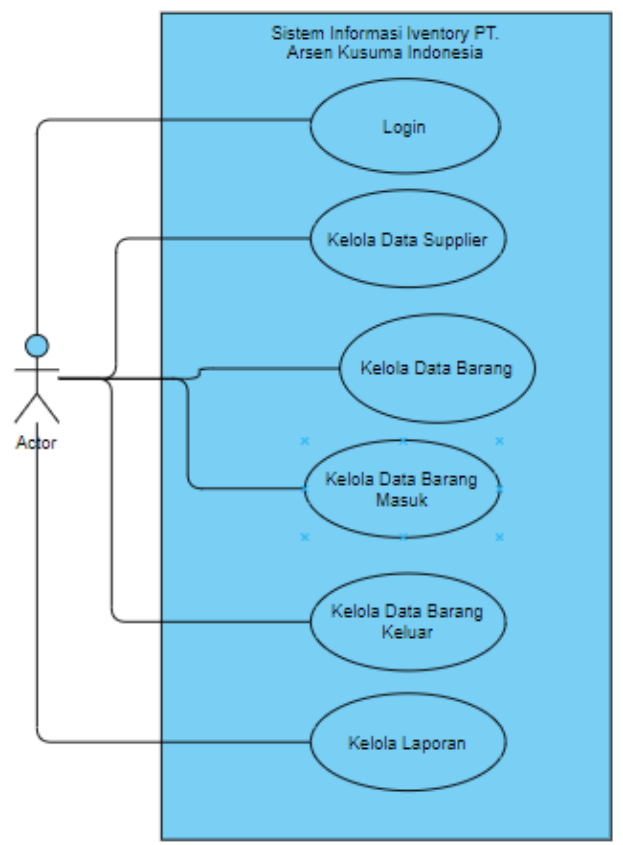

Figure 1. Use Case Diagram

In Figure 1, it is explained that actors have access to log in, Manage Supplier Data, Manage Goods Data, Manage Incoming Goods Data, Manage Outgoing Goods Data, and Manage Reports. b. Activity Diagram Modeling

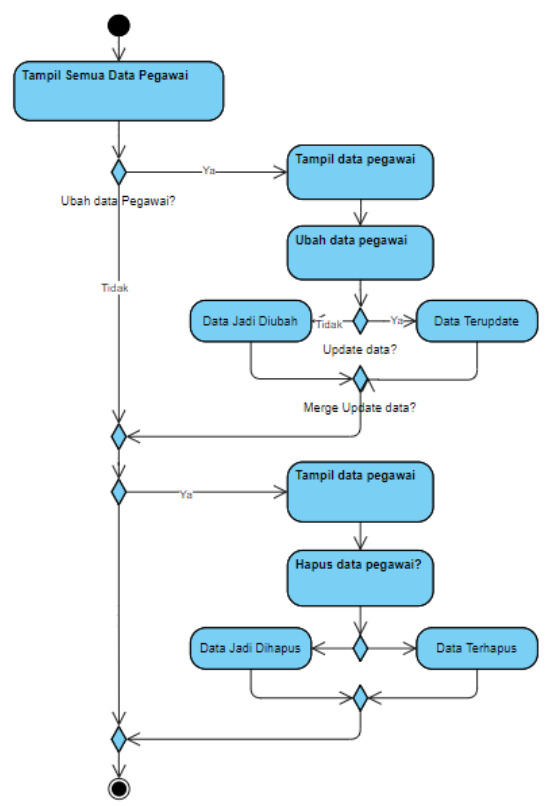

Figure 2. Activity Diagram Kelola Data Pegawai

Figure 2 above, shows the sequence of activities in the process of managing employee data.

\section{c. Class Diagram Modeling}

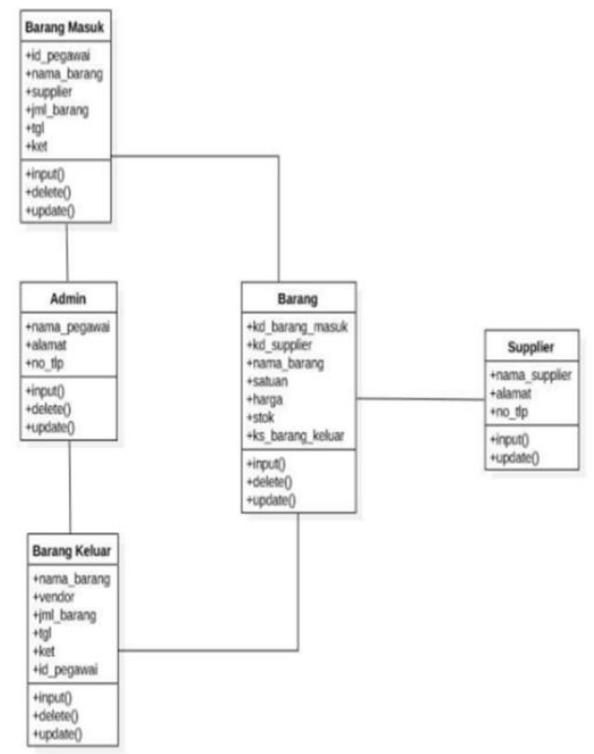

Figure 3. Class Diagram

In Figure 3, it is explained that the class diagram connects the existing classes in the design of this system, namely, there are incoming goods, admin, outgoing goods, goods, and also suppliers. 
2. Display Interface

A. Interface Form Login

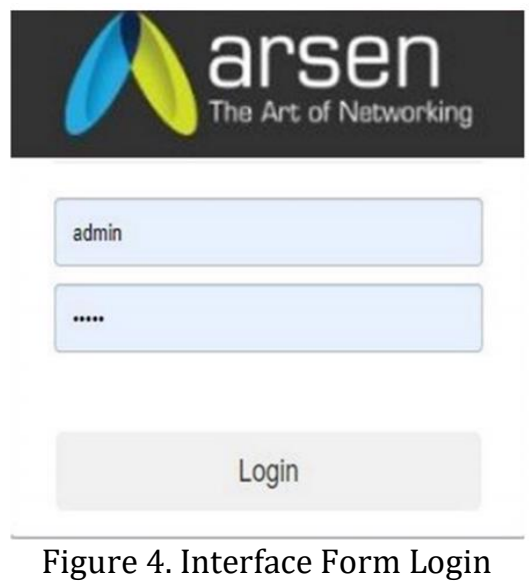

Figure 4 illustrates the display on the login form.

\section{B. Interface Main Homepage}

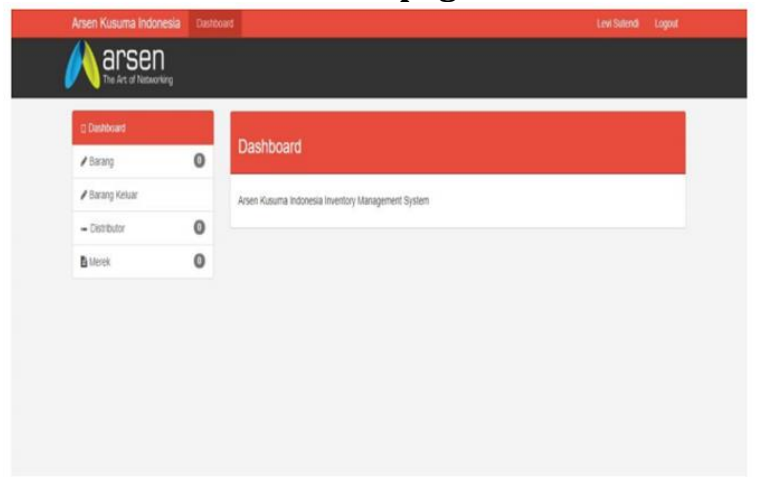

Figure 5. Interface Main Homepage

Figure 5 illustrates the display on the main homepage.

\section{Interface All Data Items}

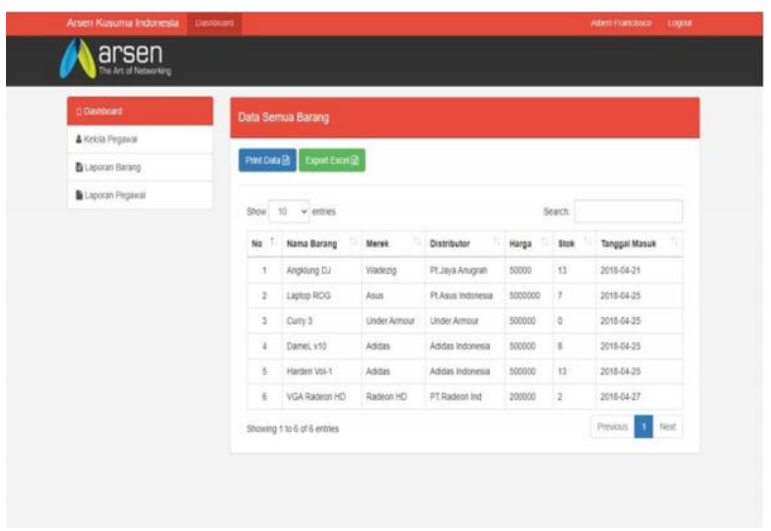

Figure 6. Interface All data items
Figure 6 illustrates the display form All Data Items. And also can choose to print data, or save data to excel format.

\section{Interface All Employee Data}

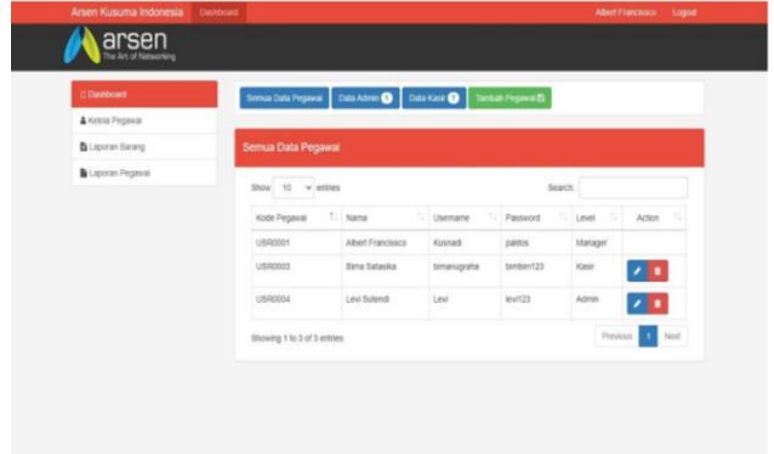

Figure 7. Interface All Employee data

Figure 7 illustrates the display on the All Employee Data page. Where here we can see all employee data, admin data, cashier data, and add employee data.

\section{E. Items Out Interface}

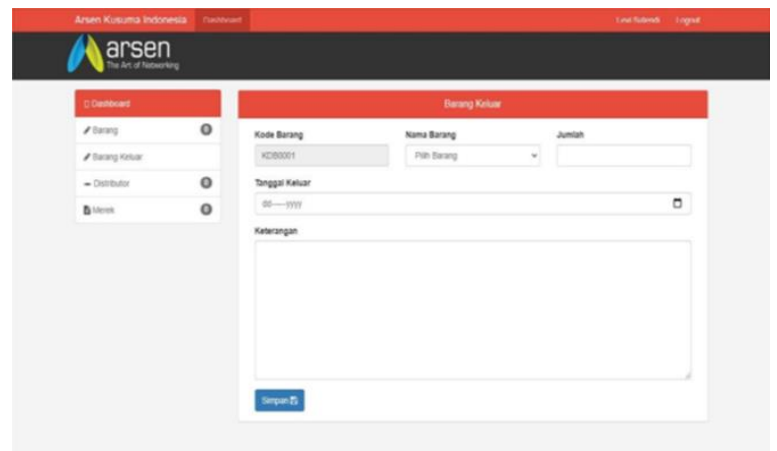

Figure 8. Items Out Interface

Figure 8 depicts the Goods Out page. It is on this page that all outgoing goods data are input.

\section{F. Period Goods Report Interface}

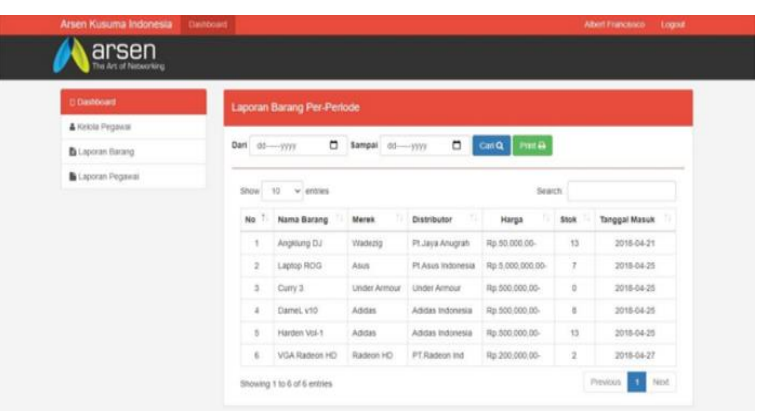

Figure 9. Period Goods Report Interface 
Figure 9 illustrates the Period Goods Report page. This report can be printed based on the required period.

\section{Code}

The following is the source-code for data stocking on the goods in the PT. Arsen Kusuma Indonesia.

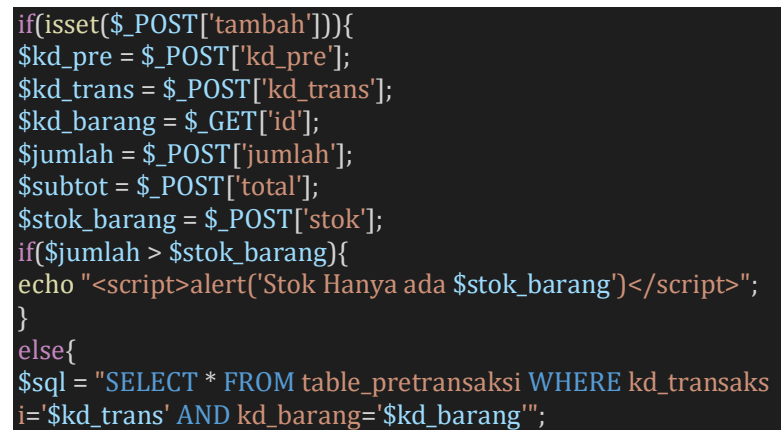

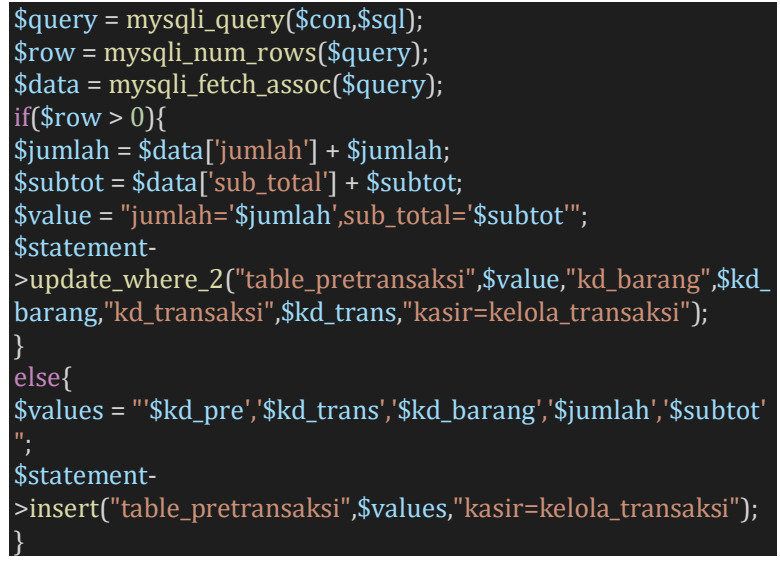

\section{Testing}

The test used in this study uses Black-box Testing, as seen in Table 1 below:

\begin{tabular}{|c|c|c|c|c|}
\hline No. & Form Uji & Skenario Uji & Hasil Yang Diharapkan & Hasil Pengujian \\
\hline 1 & Tampilan Login & $\begin{array}{l}\text { Mengisi Username dan Password } \\
\text { dengan benar }\end{array}$ & Berhasil Masuk ke Menu Utama & Sukses \\
\hline 2 & Tampilan Menu Utama & $\begin{array}{l}\text { - Membuka Menu Barang } \\
\text { - Membuka Menu Barang Keluar } \\
\text { - Distributor }\end{array}$ & $\begin{array}{ll}\text { - } & \text { Muncul Form Data Barang } \\
\text { - } & \text { Muncul Form Data Barang } \\
& \text { Keluar } \\
\text { - } & \text { Muncul Form Distributor } \\
\end{array}$ & Sukses \\
\hline 3 & Tampilan Data Semua Barang & $\begin{array}{l}\text { - Membuka Menu Print Data } \\
\text { - Membuka Menu Export Excel }\end{array}$ & $\begin{array}{ll}- & \text { Muncul Form Print Data } \\
- & \text { Muncul Form Export Excel } \\
\end{array}$ & Sukses \\
\hline 4 & $\begin{array}{l}\text { Tampilan Semua Data } \\
\text { Pegawai }\end{array}$ & $\begin{array}{l}\text { - Membuka Menu Semua Data } \\
\text { Pegawai } \\
\text { - Membuka Menu Data Admin } \\
\text { - Membuka Menu Data Kasir } \\
\text { - Menambah Data Pegawai }\end{array}$ & $\begin{array}{ll}- & \text { Muncul Form Semua Data } \\
& \text { Pegawai } \\
\text { - } & \text { Muncul Form Data Admin } \\
\text { - } & \text { Muncul Form Data Kasir } \\
\text { - } & \text { Data Pegawai dapat } \\
& \text { ditambah } \\
\end{array}$ & Sukses \\
\hline 5 & Tampilan Tambah Barang & Menambah Data Barang & Data Barang dapat ditambah & Sukses \\
\hline 6 & Tampilan Tambah Distributor & Menambah Data Distributor & Data Distributor dapat ditambah & Sukses \\
\hline 7 & Tampilan Barang Keluar & Menambah Data Barang Keluar & $\begin{array}{l}\text { Data Barang Keluar dapat } \\
\text { ditambah }\end{array}$ & Sukses \\
\hline 8 & $\begin{array}{l}\text { Tampilan Laporan Barang } \\
\text { Periode }\end{array}$ & $\begin{array}{l}\text { Menampilkan Laporan Barang } \\
\text { Periode }\end{array}$ & $\begin{array}{l}\text { Data Laporan Barang Periode } \\
\text { dapat ditampilkan }\end{array}$ & Sukses \\
\hline
\end{tabular}

\section{E. Support}

Describes the use of the software and hardware used in the proposed system and describes it in the configuration form. Generally, in a system that has many problems, especially in its maintenance, a system needs to be redeveloped to support the data processing needs by using hardware and software. Hardware is a physical factor of a computer that can work optimally and the better the software, the easier it is to process data. The two supporting suggestions constitute a unity that must support each other so that they can be maximally utilized.

a. Hardware Specifications 1) Intel (R) Core (TM) i5-8250U Processor 2) 4Gb Memory 3) 1 Terabyte Hard Disk 4) 2 Gb Shared Memory 5) Mouse 6) Keyboard 7) Monitor with a minimum screen resolution of $1024 \times 768$. b. Software Specifications The software used to support the proposed program is a. Operating System: Windows 10 b. Application Program: Sublime Text 3 c. Database: MySQL; d. Web Server: Apache 2.x e. Web Browsers: Google Chrome and Mozilla Firefox.

\section{CONCLUSIONS AND SUGGESTIONS}

Based on the results of the research that has been done, several conclusions can be drawn, namely: the design of this system is to make it easier for users to control data related to the Inventory, such as goods data reports, supplier data, incoming goods data, outgoing goods data, and goods stocks. This system built can accelerate performance in the process of data collection of incoming and outgoing goods that are systemized so that it is easier to find the required data and the existence 
of this inventory system can reduce paper accumulation. The inventory information system that is built can record order transactions, shipments, incoming and outgoing goods, and payment transactions that are computerized and with reports so that they can find out and provide fast, precise, and accurate information every day.

\section{Suggestions}

Based on the existing discussion, the authors suggest that the Inventory Information system is still limited and simple so that in the future it is hoped that it can be developed completely, such as Auto Increment to fill in item numbers automatically. It is necessary to periodically maintain the hardware and software used. Development in terms of programming language, namely from PHP to mobile programming language. It is hoped that this system will continue to be developed with the addition of useful features and more attractive design for users. There is a need for development and better maintenance of the system that has been created so that the system can be used as needed. Maintain good performance that has been achieved and implemented by the company.

\section{REFERENCE LIST}

Agus Prayitno, and Y. S. (2015). The research of negative ion test method for fabric. Pemanfaatan Sistem Informasi Perpustakaan Digital Berbasis Website Untuk Para Penulis, 1(1), 1-10. https://doi.org/10.4028/www.scientific.net/ AMR.756-759.138

Banuwati, N., Lau, E. A., \& Rahmawati, I. (2015). ANALISIS PENGENDALIAN PERSEDIAN BAHAN BAKU PADA PABRIK ROTI SARTIKA DISAMARINDA. EKONOMIA, 4(2), 152-155. http://ejurnal.untagsmd.ac.id/index.php/EKM/article/view/120 9

Barchelino, R., Ekonomi, F., Bisnis, D., Akuntansi, J., Sam, U., \& Manado, R. (2016). THE ANALYSIS OF PSAK NO.14 APPLICATION TOWARD INVENTORY RECORDING AND VALUATION METHOD AT PT. SURYA WENANG INDAH MANADO. Analisis Penerapan PSAK... Jurnal EMBA, 837(1), 837-846. https://ejournal.unsrat.ac.id/index.php/emb a/article/view/11812

Frieyadie, F. (2015). PEMBANGUNAN SISTEM INFORMASI INVENTORY MENGGUNAKAN LINEAR SEQUENTIAL MODEL UNTUK PENINGKATAN LAYANAN INVENTORY BARANG. Jurnal Techno Nusa Mandiri, 12(2),
209-114.

https://doi.org/10.33480/TECHNO.V12I2.45 1

Hutahaean, J. (2015). Konsep Sistem Informasi. Deepublish.

Irfana, D. A. (2017). PERANCANGAN SISTEM INFORMASI PERSEDIAAN BARANG (INVENTORY APPLICATION) BERBASIS WEB DAN BOOTSTRAP CSS [2017]. http://eprints.umpo.ac.id/3027/

Kushartini, D., \& Almahdy, I. (2016). Sistem Persediaan Bahan Baku Produk Dispersant Di Industri Kimia. Jurnal PASTI, 10(2), 217234.

https://publikasi.mercubuana.ac.id/index.ph p/pasti/article/view/1590

Palit, R. V, Rindengan, Y. D. Y., \& Lumenta, A. S. M. (2015). Rancangan Sistem Informasi Keuangan Gereja Berbasis Web Di Jemaat Gmim Bukit Moria Malalayang. Jurnal Teknik Elektro Dan Komputer, 4(7), 1-7. https://doi.org/10.35793/jtek.4.7.2015.104 58

Pressman, R. S. (2003). Software Engineering A Practitioner's Aproach Fifth Edition. Mc Graw Hill.

Rahardjo, M. (2011). Metode Pengumpulan Data Penelitian Kualitatif. UIN Maliki Malang. https://www.uinmalang.ac.id/r/110601/metodepengumpulan-data-penelitian-kualitatif.html

Salangka, E. (2013). Penerapan Akuntansi Persediaan Untuk Perencanaan Dan Pengendalian Lpg Pada Pt. Emigas Sejahtera Minahasa. Jurnal Riset Ekonomi, Manajemen, Bisnis Dan Akuntansi, 1(3), 1120-1128.

Stevenson, W. J., \& Chuong, S. C. (2014). Manajemen Operasi Perspektif Asia (9th ed.). Salemba Empat.

Suharti, S., \& Fong, R. (2018). ANALISIS AKUNTANSI PERSEDIAAN BARANG DAGANG PADA TOKO CEROSE HOME PEKANBARU. Bilancia : Jurnal Ilmiah Akuntansi, 2(2), 161170.

http://www.ejournal.pelitaindonesia.ac.id/oj s32/index.php/BILANCIA/article/view/60

Susilo, M., Kurniati, R., \& Kasmawi, K. (2018). RANCANG BANGUN WEBSITE TOKO ONLINE MENGGUNAKAN METODE WATERFALL. InfoTekJar (Jurnal Nasional Informatika Dan Teknologi Jaringan), 2(2), 98-105. https://jurnal.uisu.ac.id/index.php/infotekja r/article/view/171 